Hasanuddin Economics and Business Review 05:1 (2021) 26-29

\title{
The Effect of Internal Control Entities to Determining the High of Audit Fee
}

\author{
Nuryadi Winra ${ }^{\mathrm{a}, *}$, Grace T. Pontoh ${ }^{\mathrm{a}}$, Achmad Y. Paddere ${ }^{\mathrm{a}}$ \\ ${ }^{a}$ Fakultas Ekonomi dan Bisnis Universitas Hasanuddin
}

\begin{abstract}
This research aimed to find out the direct effect of the internal control entities to determining the high of audit fee, and the indirect effect of the internal control entities to determining the high of audit fee through the extension of the auditor's occupation. Data collection in this research used a questionnaire distributed to auditors who work in public accounting in Makassar. Analysis of the data used path analysis. The results of this research provided evidence that the internal control entities had a direct effect on determining the high of audit fee, and the internal control entities had a significant indirect effect through the extension of auditors' occupation to determining the high of audit fee. The implication is if internal control entities are ineffective, it will affect the larger the extent of auditor's, so it will be also affected to the highest of the amount in determining audit fee.
\end{abstract}

Keywords: internal control entities, extensive of auditor's occupation, audit fee

\section{INTRODUCTION}

Agency theory which was first published by Jensen and Meckling (1976) assumes that there is a conflict of interest between the principal as the resource owner and the agent as the resource manager. The size of the agency conflict reflects the weakness of the entity's internal control. In practice often financial statements can be misleadingly prepared by management whether intentional for a particular purpose, omission, or because of the lack of understanding of the applicable financial accounting standards. To obtain assurance that a financial report has presented financial information fairly based on financial accounting standards, the financial statements need to be audited by a public accountant. In providing an opinion on the fairness of the client's financial statements, the auditor shall obtain reasonable assurance about whether the financial statements as a whole are free from material misstatement.

As with other professions, public accountants in connection with providing professional services are entitled to a fee from their client entity. The audit fee must fairly reflect the work done for the client or the level of responsibility and risk of the public accountant. Determination of audit fees that are too low or significantly much lower than those imposed by the predecessor public accounting firm (hereinafter abbreviated as CPA firms) or proposed by other CPA firms, will raise doubts

\footnotetext{
*Author in correspondence,

Email address: nuryadiwinra16@gmail . com (Nuryadi Winra)
}

regarding the ability and competence of auditors in applying applicable technical standards and professional standards.

The Indonesian Institute of Certified Public Accountants or (IICPA) issued Management Regulation Number 2 of 2016 concerning the determination of fees for financial statement audit services as a revision of Decree No. KEP.024 / IAPI / VII / 2008 concerning policies for determining audit fees (Institut Akuntan Publik Indonesia, 2008). Management Regulation Number 2 of 2016 was issued as a guide for all IAPI members who practice as public accountants in determining a reasonable amount of standard fee for professional services provided. The auditor shall be able to estimate sufficient hours of work for the audit engagement. The auditor is not allowed to reduce the size of the work or the adequacy of audit procedures solely to reduce the number of hours of work required by the audit engagement to reduce the excess audit fee rate.

The extent of the auditor's occupation as a determining factor for the amount of the audit fee is the auditor's effort to obtain and evaluate audit evidence as a basis for providing audit opinion. The audit standard (ISA 500) states that most of the auditor's work in formulating the auditor's opinion consists of obtaining and evaluating audit evidence. The auditor may choose between alternative preliminary audit strategies in planning the extent of the auditor's occupation. The preliminary audit strategy consists of four approaches, namely: (1) the main substantive approach that emphasizes detailed testing; (2) a lower level of control risk; (3) the main substance approach that emphasizes analytical procedures; and (4) approaches to inherent risks and analytical procedures.

The extent of the auditor's occupation refers to the audit 
standard (PSA 330) explaining that in response to the assessment of the risks of material misstatement, the auditor performs further audit procedures consisting of tests of controls, substantive tests of classes of transactions, substantive analytical tests, and tests of details on balances. Tests of controls are performed to support a reduced assessment of control risk, while the auditor uses substantive analytical procedures and tests of details on balances to meet planned detection risk. The testing of the substance of the class of transactions affects the control test and the detection risk is planned because it tests the effectiveness of internal control and the transaction rupiah amount.

ISA 315 explains that an understanding of the entity's internal control assists the auditor in identifying types of potential misstatements and factors that affect the risks of material misstatement, and in designing the nature, timing, and extent of further procedures. This is in line with PSA No. 01 (SA Section 150) regarding auditing standards, the standard section of fieldwork which states that an adequate understanding of internal control must be obtained to plan the audit and determine the nature, timing, and extent of further audit procedures.

Several researchers have researched the factors that influence the determination of audit fees. Herawaty (2011) examines the effect of internal control and length of audit time on audit fees (a case study on CPA firms at Jambi and Palembang cities). The results of this study emphasize that internal control has a positive effect on the audit fee set by CPA firms, while the length of time for the audit has a positive effect on the audit fee set by CPA firms. These results support the research conducted by Hay et al. (2008); Purnamasari and Nasikin (2012); Elzan et al. (2015); Andini (2017); Hartati et al. (2017); Kusumajaya (2017); and Puspita and Septiani (2018).

However, the results of different studies conducted by Widiasari and Jatmiko (2008); Chandra (2015); Rahayu (2017); Ananda and Triyanto (2019), and Sitompul (2019) show that the entity's internal control does not have a significant effect on the determination of audit fees.

This research refers to research conducted by Herawaty (2011) which examines the effect of internal control and the length of audit time on audit fees (a case study on CPA firms at Jambi and Palembang cities). The difference in this study is to reduce the independent variable, namely the length of the audit time, and to add an intervening variable, namely the extent of the auditor's occupation. In addition, respondents in this study were public accountants who worked at CPA firms in Makassar.

Based on the description of the background of the research, the problem formulation in this study is whether the entity's internal control has a direct and indirect effect on the high of the audit fee with the extent of the auditor's occupation as an intervening variable. The purpose of this study is to prove the direct effect of the entity's internal control on the high of the audit fee and the indirect effect of the entity's internal control on the high of the audit fee with the extent of the auditor's occupation as an intervening variable.

\section{METHOD}

\subsection{Method of Collecting Data}

The type of research is hypothesis testing through correlational studies. The research data were obtained from primary sources with questionnaires as a method of data collection. The questionnaire was given to public accountants who work at CPA firms in the Makassar area. The statement in this research questionnaire is measured using a Likert scale.

\subsection{Population and Sample}

The population in this study includes all staff auditors, both junior and senior auditors who work at 13 Certified Public Accounting firms (CPA Firms) in the city of Makassar which are listed in the directory 2019 Kantor Akuntan Publik dan public accountant. The reason for choosing the city of Makassar is because it is one of the largest cities in Eastern Indonesia. The sampling method used in this study was saturated or census samples, in which all members of the population were used as research samples. The number of respondents in this study was 31 respondents.

\subsection{Data Analysis}

This research uses the path analysis method. This study aims to determine the direct effect of the entity's internal control on the high of the audit fee and the indirect effect of the entity's internal control on the high of the audit fee with the extent of the auditor's work as an intervening variable. Hypothesis testing is done by using the T-test:

$H_{1}: \beta_{2}>0$ The entity's internal control (X) has a direct positive effect on the high of the audit fee $(Y)$.

$H_{2}: \beta_{1} \times \beta_{3}>0$. The entity's internal control $(\mathrm{X})$ has an indirect positive effect on the high of the audit fee (Y) with the area of the auditor's occupation (M) as an intervening variable.

The calculation result ( $\mathrm{p}$-value) is then compared with a confidence level of $95 \%(\alpha=0.05)$ with the following decision criteria: If p-value $\leq 5 \%$, then $H_{1}$ and $H_{2}$ are rejected, otherwise $H_{1}$ and $H_{2}$ are accepted. The following are the equations used in the study:

$$
\begin{aligned}
M & =\alpha+\beta_{1} X+e_{1} \\
Y & =\alpha+\beta_{2} X+\beta_{3} M+e_{2}
\end{aligned}
$$

$\mathrm{Y}$ indicates the high of the audit fee, $\mathrm{M}$ indicates the extent of the auditor's occupation, $\mathrm{X}$ indicates the entity's internal control. Whereas shows a constant, $\beta_{1}, \beta_{2}, \beta_{3}$ shows the regression coefficient, and $e_{1}$ and $e_{2}$ indicate an error.

\section{RESULT AND DISCUSSION}

Based on the results of data processing using path analysis, the following equation is obtained.

$$
\begin{aligned}
M & =26.810+0.526 X+e_{1} \\
Y & =9.555+0.364 X+0.532 M+e_{2}
\end{aligned}
$$


The value of the $\mathrm{R}$ square for the variable $\mathrm{M}$ is 0.277 . This indicates that the contribution of the influence of the entity's internal control variable $(\mathrm{X})$ to the auditor's occupation area (M) is $27.7 \%$ while the remaining $72.3 \%$ is the contribution of other variables not included in this study.

The $\mathrm{R}$ square value for the $\mathrm{Y}$ variable is 0.619 . This indicates that the contribution of the influence of the entity's internal control variable (X) and the extent of the auditor's occupation area (M) to the determination of the high of the audit fee (Y) is $61.9 \%$ while the remaining $38.1 \%$ is the contribution of other variables not included in this research.

Hypothesis one $\left(H_{1}\right)$ examines the direct effect between the entity's internal control variable $(\mathrm{X})$ on the high of the audit fee $(\mathrm{Y})$, which has a significant level of 0.013 and a calculated $t$ value is 2.654 . The significance level is $; 0.05$ and the $t$ value $i$ 2.042 , so there is a significant direct influence between the entity's internal control variables $(\mathrm{X})$ on the determination of the high audit fee $(\mathrm{Y})$. The results of this test indicate that hypothesis one $\left(H_{1}\right)$ is accepted.

Hypothesis two $\left(H_{2}\right)$ examines the direct effect between the entity's internal control variables (X) on the extent of auditor's occupation (M) and between the extent of auditor's occupation (M) on the high of the audit fee (Y). The entity's internal control variable $(\mathrm{X})$ has a significant level of 0.002 and a calculated $\mathrm{t}$ value is 3.330 . The significance level $; 0.05$ and the $t$ value $i$ 2.042 , so there is a significant direct influence between the entity's internal control variables (X) on the extent of the auditor's work (M).

Testing the direct effect between the variable of the extent auditor's occupation $(\mathrm{M})$ on the high of the audit fee $(\mathrm{Y})$, obtained a significance level of 0.001 and a t-value is 3.876. The significance level is ; 0.05 and the $t$ value $i 2.042$, so there is a significant direct influence between the variable of the extent of auditor's occupation (M) on the determination of the high of the audit fee (Y). The test results show that the entity's internal control variable $(\mathrm{X})$ has an indirect significant effect on the determination of the high of the audit fee $(\mathrm{Y})$ through the extent of the auditor's occupation (M) as an intervening variable. The results of this test indicate that hypothesis two $\left(\mathrm{H}_{2}\right)$ is accepted.

The results of hypothesis testing provide evidence that the entity's internal control variable $(\mathrm{X})$ has a significant direct and indirect effect on the determination of the high audit fee $(\mathrm{Y})$. The magnitude of the indirect effect is $(0.532 \times 0.526)=0.280$. Since the direct relationship coefficient of 0.364 is greater than the coefficient of the indirect relationship of 0.280 , it can be concluded that the real relationship is a direct relationship. The total effect of the entity's internal control variable (X) on the determination of the high of the audit fee is 0.644 .

The test results show that the entity's internal control has a significant direct effect on the determination of the high audit fee in the city of Makassar. Given that the beta coefficient is positive, it indicates a positive and significant effect between the entity's internal control on the determination of the high of the audit fee. The test results also show that the entity's internal control has a significant and positive indirect effect on the determination of the high audit fee through the extent of the auditor's occupation in the city of Makassar.
The meaning of the test results shows that the more ineffective the entity's internal control is, the wider the auditor's work will be, so the greater the determination of the audit fee by the auditor. The entity's internal control, which consists of the control environment, risk assessment, information and communication systems, control and monitoring activities, provides a useful framework for the auditor to obtain an adequate understanding that may affect the establishment of further audit procedures. This means that when the entity has effective internal control, it will have an impact on the planning and determination of the area of work less so that it also affects the determination of a smaller audit fee.

This research is in line with agency theory which was first published by Jensen and Meckling (1976) assume that there is a conflict of interest between the principal as the resource owner and the agent as the resource manager. The size of the agency conflict reflects the weakness of the entity's internal control so that the principal establishes a supervisory mechanism, in this case, it is carried out by the external auditor. The greater the agency conflict, the greater the agency cost that arises from the oversight mechanism carried out by external auditors because public accountants must obtain relevant and reliable evidence to obtain adequate confidence. The more relevant and reliable the evidence that must be collected by the auditor, the broader the auditor's work will be, and the higher the audit fee will be determined.

The findings of this study are consistent with previous research by Herawaty (2011) which proves that internal control and the length of audit time have a positive effect on audit fees. The results of this study are also in line with research conducted by Hay et al. (2008); Purnamasari and Nasikin (2012); Elzan et al. (2015); Andini (2017); Hartati et al. (2017); Kusumajaya (2017); and Puspita and Septiani (2018).

However, the results of different studies conducted by Widiasari and Jatmiko (2008); Chandra (2015); Rahayu (2017); Ananda and Triyanto (2019), and Sitompul (2019) shows that the entity's internal control does not have a significant effect on the determination of the audit fee.

\section{CONCLUSION}

This research uses agency theory. The results showed that the entity's internal control had a positive and significant effect directly on the determination of the high of the external auditor's audit fee. In addition, the entity's internal control has a positive and significant indirect effect on the high of the audit fee with the extent of the auditor's occupation as an intervening variable. Based on the conclusion, the following suggestions can be made. The auditor must obtain an adequate understanding of the entity's internal control to plan the audit and determine the nature, timing, and scope of tests to be performed so that the auditor can determine the overall audit fee rate. For further researchers, they can assess other variables, such as the level of expertise that influences the determination of the high of the audit fee, as well as using different research methods so that they do not cause differences in interpretation, for example using qualitative research methods. 


\section{References}

Ananda, S. S., Triyanto, D. N., 2019. Pengaruh Fungsi Audit Internal, Risiko Perusahaan, dan Komplektisitas Perusahaan terhadap Fee Audit (Studi Empiris pada Perusahaan Keuangan yang Terdaftar Di Bursa Efek Indonesia Periode 2016-2018). Journal Accounting and Finance 3 (1).

Andini, 2017. Pengaruh Fungsi Audit Internal terhadap Fee Auditor Eksternal pada Perusahaan Non Keuangan yang Terdaftar di BEI. Jurnal Akuntansi STIEM 3 (2), 46-62.

Chandra, M. O., 2015. Pengaruh Good Corporate Governance, Karakteristik Perusahaan dan Ukuran KAP terhadap Fee Audit Eksternal. Jurnal Akuntansi Bisnis 8 (26), 174-194.

Elzan, M., Pernamasari, P., Utomo, H., 2015. Pengaruh Fungsi Audit Internal terhadap Audit fee dengan Penerapan Good Corperate Governance sebagai Variabel Intervening. Prosiding Penelitian 1 (1), 372-378.

Hartati, S. T., Wiharno, H., Nurhayati, E., 2017. Pengaruh Risiko Audit dan Lamanya Waktu Audit terhadap Penetapan Audit Fee. Jurnal Riset Keuangan dan Akuntansi 3 (1), 95-104.

Hay, D., Robert, K. W., Ling, H., 2008. Evidence on the Impact of Internal Control and Corporate Governance on Audit fees. International Journal of Auditing 12, 9-24.

Herawaty, N., 2011. Pengaruh Pengendalian Intern dan Lamanya Waktu Audit terhadap Fee Audit (Studi Kasus pada Kap Kota Jambi dan Palembang). Jurnal Penelitian Universitas Jambi 13 (1), 7-12.

Institut Akuntan Publik Indonesia, 2008. Surat Keputusan No. KEP.024/IAPI/VII/2008.
Jensen, M., Meckling, H., 1976. Theory of the Firm: Managerial Behaviour, Agency Cost, and Ownership Structure. Journal of Financial Economic 3, 305-360.

Kusumajaya, A., 2017. Faktor-faktor yang Mempengaruhi Fee Audit Eksternal pada Perusahaan Manufaktur yang Terdaftar di Bursa Efek Indonesia. Jurnal Akuntansi 12 (2), 167-185.

Purnamasari, D., Nasikin, 2012. Pengaruh Audit Risk (Inheren Risk, Control Risk, dan Detektion Risk) terhadap Penentuan Audit Fee (Studi Empiris pada Kantor Akuntan Publik di Wilayah Malang, Surabaya, dan Jakarta). Jurnal Ilmiah Mahasiswa FEB 2 (2), 1-17.

Puspita, A. P., Septiani, T., 2018. Pengaruh Ukuran Dewan Komisaris, Komite Audit, dan KAP terhadap Fee Audit Eksternal. Jurnal Akuntansi 12 (1), 115.

Rahayu, S., 2017. Analisis Pengaruh Audit Risk, Ukuran Perusahaan dan Internal Audit terhadap Fee Audit Eksternal (Studi Empiris pada Perusahaan Perdagangan, Jasa dan Investasi Lainnya yang Terdaftar dalam BEI (Bursa Efek Indonesia) Tahun 2013-2015)

Sitompul, F., 2019. Pengaruh Mekanisme Good Corporate Governance dan Karakteristik Perusahaan terhadap Audit fee Eksternal (Studi pada Perusahaan Manufaktur yang Terdaftar di Bursa Efek Indonesia). Ikraith Ekonomika 2 (01).

Widiasari, S., Jatmiko, W. P., 2008. Pengaruh Pengendalian Internal Perusahaan dan Struktur Corporate Governance terhadap Fee Audit. Jurnal Akuntansi dan Investasi 9 (2), 113-125. 